\title{
Possibilities and limitations in the utilization of the Neogene geothermal reservoirs in the Great Hungarian Plain, Hungary
}

\section{László Lenkey}

Geological, Geophysical and Space Science

Research Group Hungarian Academy of Sciences

and Eötvös Loránd University, Budapest

Judit Mádl-Szőnyi

Department of General and Applied Geology

Eötvös Loránd University, Budapest

\section{Ferenc Zsemle}

Department of General and Applied Geology

Eötvös Loránd University, Budapest

\author{
Péter Dövényi \\ Department of Geophysics and Space Sciences \\ Eötvös Loránd University, Budapest
}

Ladislaus Rybach

Institute of Geophysics

Swiss Federal Institute of Technology, Zurich

\begin{abstract}
Hungary has favorable geothermal conditions. The paper discusses the thermal and hydrogeologic conditions of the Neogene groundwater reservoir below the Great Hungarian Plain. In the exploration of the reservoir one of the most problematic issues, is the interaction between gravitydriven and overpressured flow regimes, especially along conductive faults. A combination of structural geology supported by seismic interpretation, hydrogeochemistry, and hydraulic evaluations can help to delineate the two flow regimes and determine the origin of the water: meteoric (and thus rechargeable) or syn-sedimentary (and thus non-rechargeable) pore water. These results can be incorporated into basin-scale digital models of the Neogene reservoir. The models can be used to predict the response of the reservoir to the water production and injection, and can help to exploit more efficiently and sustainably the thermal waters of the Great Hungarian Plain reservoir.
\end{abstract}

Key words: Neogene reservoir, geothermal conditions, utilization, production and injection, Great Hungarian Plain

\section{Introduction}

The utilization of geothermal energy has a long tradition in the Pannonian Basin and Hungary. Hot springs, arising along faults, were used for bathing and heating by the ancient Romans in the city of Aquincum, capital of the Province of Pannonia. In medieval times hot water was used in Turkish spas. One of the first deep drillings in the world (Mc Farland 2002) was carried out by Vilmos Zsigmondy in Budapest between 1868 and 1878 (Zsigmondy 1871). Since then

Addresses: L. Lenkey, F. Zsemle, J. Mádl-Szónyi, P. Dövényi: H-1117 Budapest, Pázmány P. sétány 1/C, Hungary, e-mail: lenkey@pangea.elte.hu L. Rybach: CH-8092 Zurich, Sonneggstr. 5, Switzerland

Received: September 1, 2008; accepted: January 22, 2009 
this well has been supplying thermal water at a temperature of $74^{\circ} \mathrm{C}$ from depth of $970 \mathrm{~m}$. The central heating of some apartment blocks in Budapest was already operated by thermal water in the 1920s and 1930s (Schulhof 1957). The boost of geothermal heat utilization in Hungary began in the late 1950s with the application of thermal water in greenhouse heating. Nowadays, based on heating capacity data, thermal waters are mainly used for balneological purposes $(50.4 \%)$, in green houses $(28.3 \%)$, and to a lesser extent for communal heating (14.5\%), industrial and other purposes (6.8\%) (Árpási 2005).

Worldwide the technical potential of geothermal energy is the highest $(5000$ EJyear $^{-1}$ ) among all renewable energy sources (WEA 2000). Utilization of geothermal energy has been increasing by $\sim 3 \%$ on a yearly average (Bertani 2007) and this increase is assumed to continue (Fridleifsson et al. 2008). The use of geothermal energy produces less contamination than fossil energy consumption; moreover, geothermal energy can be produced sustainably and is independent of meteorological conditions, unlike wind and solar energy. The share of geothermal energy in the total energy balance of Europe and Hungary is 5.5\% and $0.29 \%$, respectively (Árpási 2005). In spite of favorable thermal and hydrogeologic conditions the utilization of geothermal energy in Hungary is low compared to the leading European countries (Lund et al. 2005).

In this paper the thermal and hydrogeologic conditions of the Neogene groundwater reservoir beneath the Great Hungarian Plain are discussed. Suggestions are given on how to exploit the thermal water resource more efficiently, and what kind of research and developments are necessary to achieve this goal.

\section{Geologic background}

The Pannonian Basin is a roughly circular topographic depression surrounded by the Alps, the Carpathians and the Dinaric mountain chains. The basin was formed during the Early-Middle Miocene (17.5-12.5 Ma) as the northeastward and eastward rollback subduction of a remnant oceanic lithospheric plate led to back-arc extension in the Pannonian Region (Royden et al. 1983; Csontos et al. 1992). Several deep troughs and grabens were formed, which were filled with sediments. During the early stage of sedimentation sediment supply areas were far from the center of the basin; therefore fine-grained sediments, mainly shale and marl, were accumulated in the deep troughs (Juhász 1991). Later, the uplifting Carpathian arc provided a rich sediment source, and the basin was filled up by a large fluvial system prograding from the NW, N and NE (Vakarcs et al. 1994). Finally, lacustrine and fluviatile sediments were deposited.

Due to the Early-Middle Miocene extension the Pannonian lithosphere was thinned out, resulting in an elevated geothermal gradient in the lithosphere, and thus, high surface heat flow (Royden et al. 1983). Heat flow in the Pannonian Basin (Fig. 1) varies between 80 and $110 \mathrm{mWm}^{-2}$ (Dövényi et al. 2002), which is 


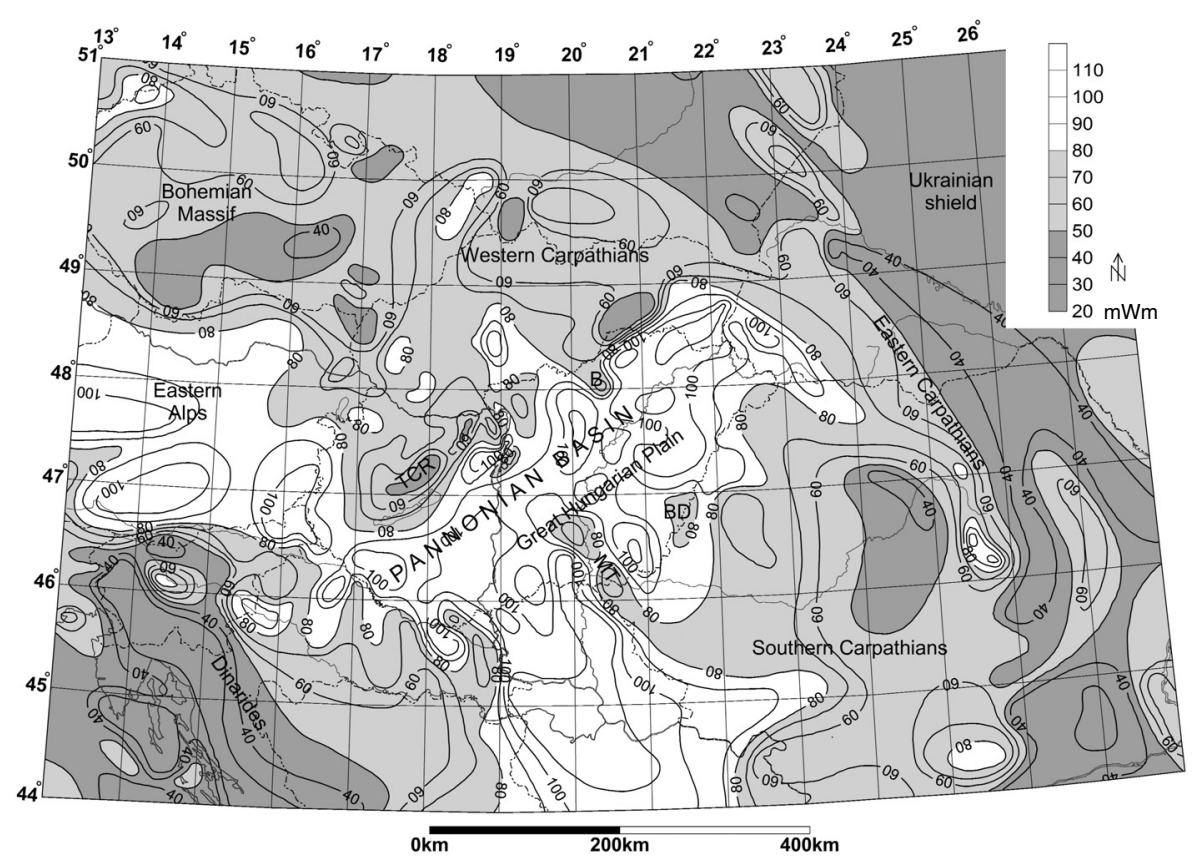

Fig. 1

Heat flow in the Pannonian Basin and the surrounding regions (after Dövényi et al. 2002). Contour interval is $10 \mathrm{mWm}^{-2}$. TCR - Transdanubian Central Range, B - Bükk Mts., M - Makó Trough, BD Békés Depression

considerably above the continental average of $65 \mathrm{mWm}^{-2}$ (Pollack et al. 1993). The average geothermal gradient in Hungary is $45{ }^{\circ} \mathrm{Ckm}^{-1}$. Due to the high geothermal gradient, groundwater with outflow temperature above $30{ }^{\circ} \mathrm{C}$ is available in $70 \%$ of the area, and everywhere in the Great Hungarian Plain (Mádlné Szőnyi 2006).

\section{Geothermal conditions}

The most important physical properties in geothermal exploration are heat flow, subsurface temperature and hydraulic parameters of the geothermal reservoirs. Heat flow is not uniformly distributed in the Pannonian Basin (Fig. 1). Carbonate outcrops (Transdanubian Central Range, Bükk, Dinarides) are characterized by low to medium heat flow $\left(30-50 \mathrm{mWm}^{-2}\right)$ due to the intensive infiltration of meteoric water. Heat flow is generally high, $100-110 \mathrm{mWm}^{-2}$ (Dövényi et al. 2002) in the Great Hungarian Plain, but it is lower $\left(70-90 \mathrm{mWm}^{-2}\right.$ ) in the area of deep troughs (Makó and Békés Subbasins). The relatively low heat flow has two explanations. Sediments were deposited at ambient temperature, and due to their great thickness (max. $7 \mathrm{~km}$ ) they have not yet been completely 
heated up (Lenkey 1999). On the other hand, sediments have lower thermal conductivity $\left(1.5-2.0 \mathrm{Wm}^{-1{ }^{\circ}} \mathrm{C}^{-1}\right)$ than the basement $\left(3-3.5 \mathrm{Wm}^{-1{ }^{\circ}} \mathrm{C}^{-1}\right)$; therefore heat flow is conducted toward the basement highs (Bodri 1981).

Subsurface temperature conditions in Hungary are known from more than 15,000 temperature data measured in more than 5,000 wells, excluding data of wells of less than $200 \mathrm{~m}$ depth unless the temperature in those wells is above $30{ }^{\circ} \mathrm{C}$ (Dövényi et al. 2002). At $500 \mathrm{~m}$ depth the average temperature is $35-40{ }^{\circ} \mathrm{C}$ (Fig. 2). Temperatures can reach $45-70{ }^{\circ} \mathrm{C}$ at $500-1,000 \mathrm{~m}$ depth due to the heating effect of upwelling groundwater (Erdélyi 1976). The influence of thermal convection ceases at 2,000 $\mathrm{m}$ depth; there the pattern of temperature distribution is similar to the pattern of heat flow distribution. Thus the temperature is lower beneath the deep troughs $\left(80-100{ }^{\circ} \mathrm{C}\right)$ (Fig. 3), and higher in the central and southeastern part of the Great Hungarian Plain $\left(110-120{ }^{\circ} \mathrm{C}\right)$. The average temperature at $2,000 \mathrm{~m}$ depth is $100-110^{\circ} \mathrm{C}$.

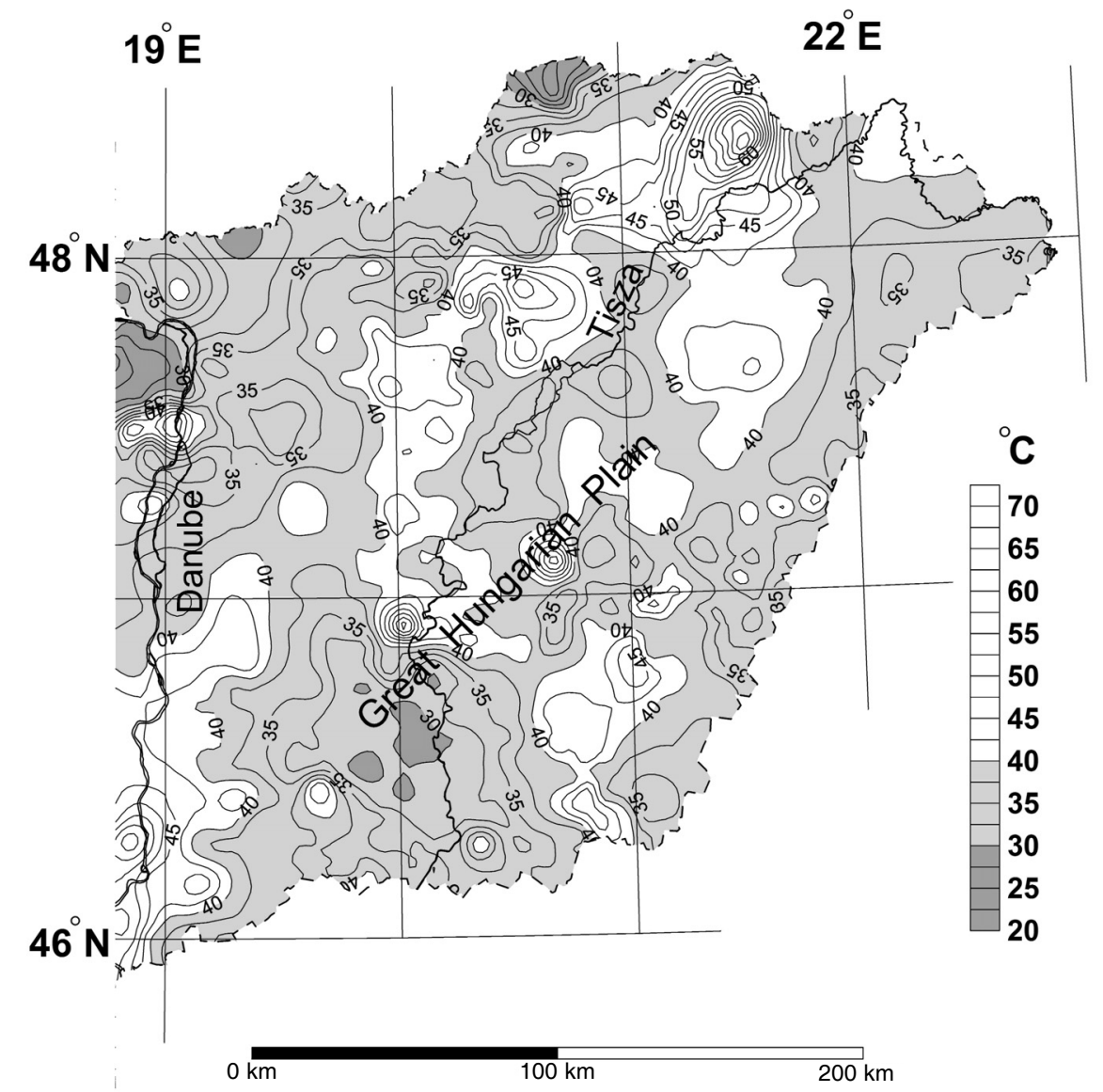

Fig. 2

Temperature at $500 \mathrm{~m}$ depth below ground surface in the Great Hungarian Plain. Contour interval is $2.5^{\circ} \mathrm{C}$ 


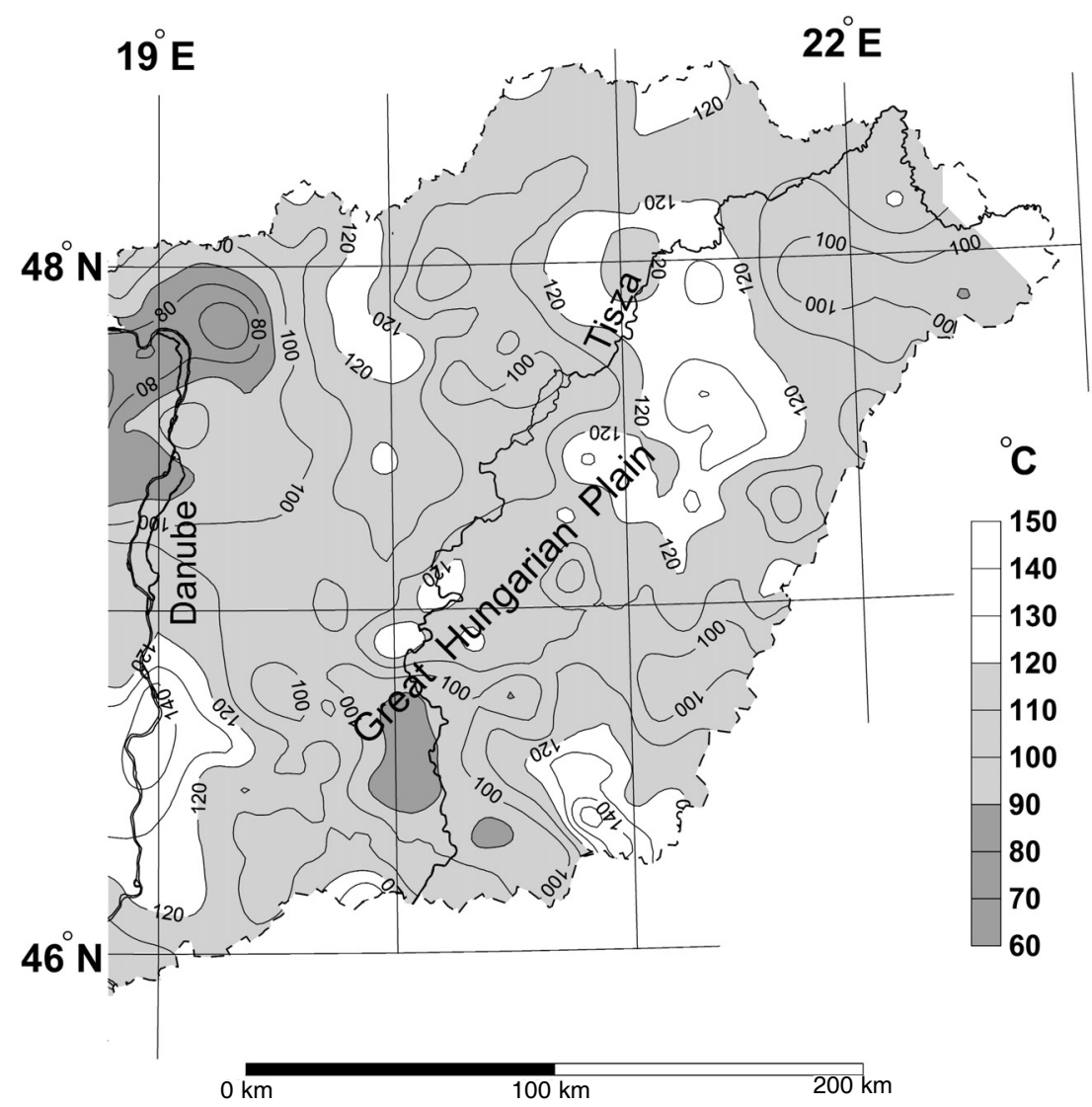

Fig. 3

Temperature at 2,000 $\mathrm{m}$ depth below ground surface in the Great Hungarian Plain. Contour interval is $10^{\circ} \mathrm{C}$

\section{Hydrogeologic conditions}

The Great Hungarian Plain, as a part of the Pannonian Basin, consists of Neogene basin fill. The semi- to unconsolidated marine, lacustrine and fluviatile clastic sediments rest upon a strongly tectonized Pre-Neogene basement of horst and graben topography, with relief in excess of $5 \mathrm{~km}$ (Bérczi et al. 1988; Juhász 1991) (Fig. 4). The thickness of the Neogene sediments varies between $100 \mathrm{~m}$ at the basin flanks and $7 \mathrm{~km}$ in the grabens (Kilényi et al. 1991). The Neogene sediments form a continuous aquifer system (Erdélyi 1976; Tóth and Almási 2001).

In the upper $200-1,700 \mathrm{~m}$-deep part of this aquifer, gravity-driven regional groundwater flow occurs (Tóth and Almási 2001), which has been well known for decades (e.g. Erdélyi 1976). Recharge areas are located in topographic highs, and 


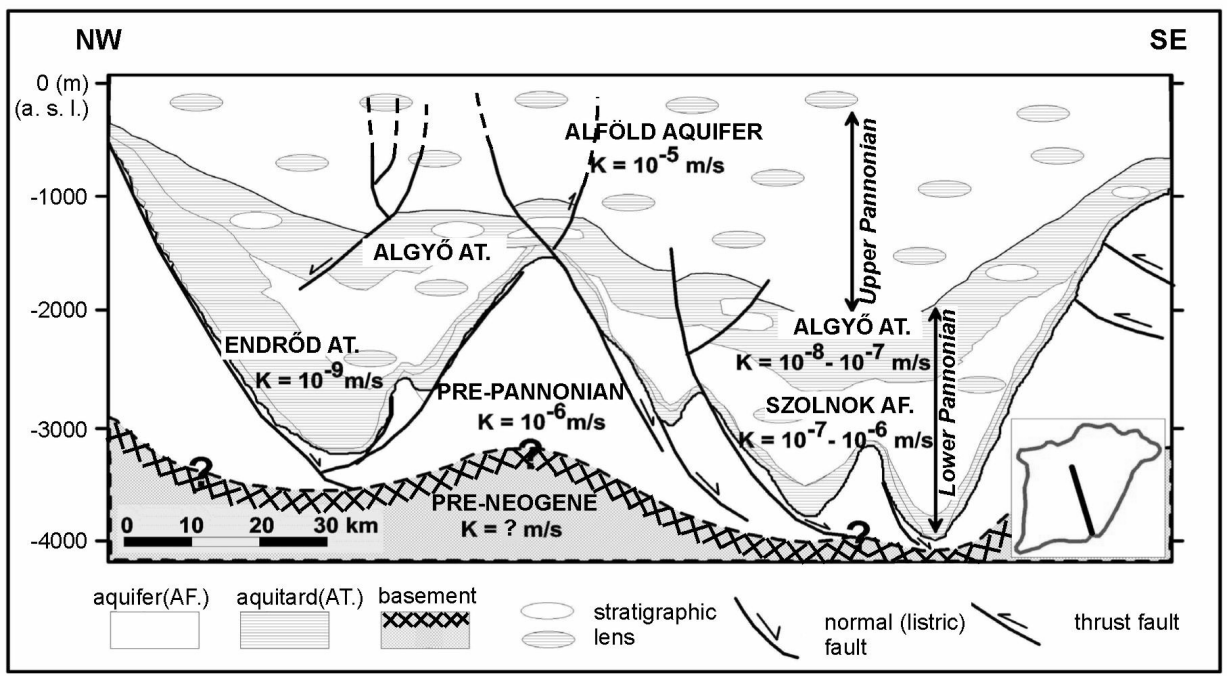

Fig. 4

A NW-SE directed schematic hydrogeologic section across the Great Hungarian Plain (modified from Tóth and Almási 2001; Fig. 8, p. 17; Juhász 1991)

discharge areas are found at topographic lows. The yield from the sand and sandstone aquifer (Alföld Aquifer) can reach $10-100 \mathrm{~m}^{3} \mathrm{~h}^{-1}$, depending on the regional hydraulic conductivity $\left(\mathrm{K}_{\mathrm{r}}=10^{-5} \mathrm{~ms}^{-1}\right)$ (Tóth 2006).

The high hydraulic conductivity sediments are underlain by clay and marl, which form aquitards (Algyő Aquitard, $\mathrm{K}=10^{-8}-10^{-7} \mathrm{~ms}^{-1}$; Endrőd Aquitard, $\mathrm{K}=10^{-9} \mathrm{~ms}^{-1}$ ). Sandstone bodies, i.e. aquifers, are interbedded between the aquitards (Szolnok Aquifer, $\mathrm{K}=10^{-7}-10^{-6} \mathrm{~ms}^{-1}$ ) (Fig. 4).

\section{Scientific uncertainties in the utilization of Neogene reservoirs}

Deep aquitards and underlying aquifers in the Neogene sequence in general are overpressured; however, Tóth and Almási (2001) realized that the Algyó Aquitard can be characterized by near hydrostatic pressure or overpressure, depending on local hydraulic conditions.

In the vicinity of Szentes and Csongrád, the pressure gradient is slightly above hydrostatic, indicating gravitationally-driven upward groundwater flow (Fig. 5). These indicate rechargeable conditions and are favorable for groundwater and heat production (Tóth 2006).

In other places, for instance near Biharkeresztes, overpressure appears at 1,200 $\mathrm{m}$ with a value of 2-6 MPa and reaches $>10 \mathrm{MPa}$ at a depth of 2,200 $\mathrm{m}$ (Fig. 6).

According to Tóth and Almási (2001) the dissipation of the overpressure is connected to sedimentary windows and faults. Conductive faults may discharge the pore water of the overpressured regime into the gravity-driven regional 
Fig. 5

Approximate hydrostatic pressure gradient (modified from Tóth and Almási 2001; Fig. 10, p. 19)

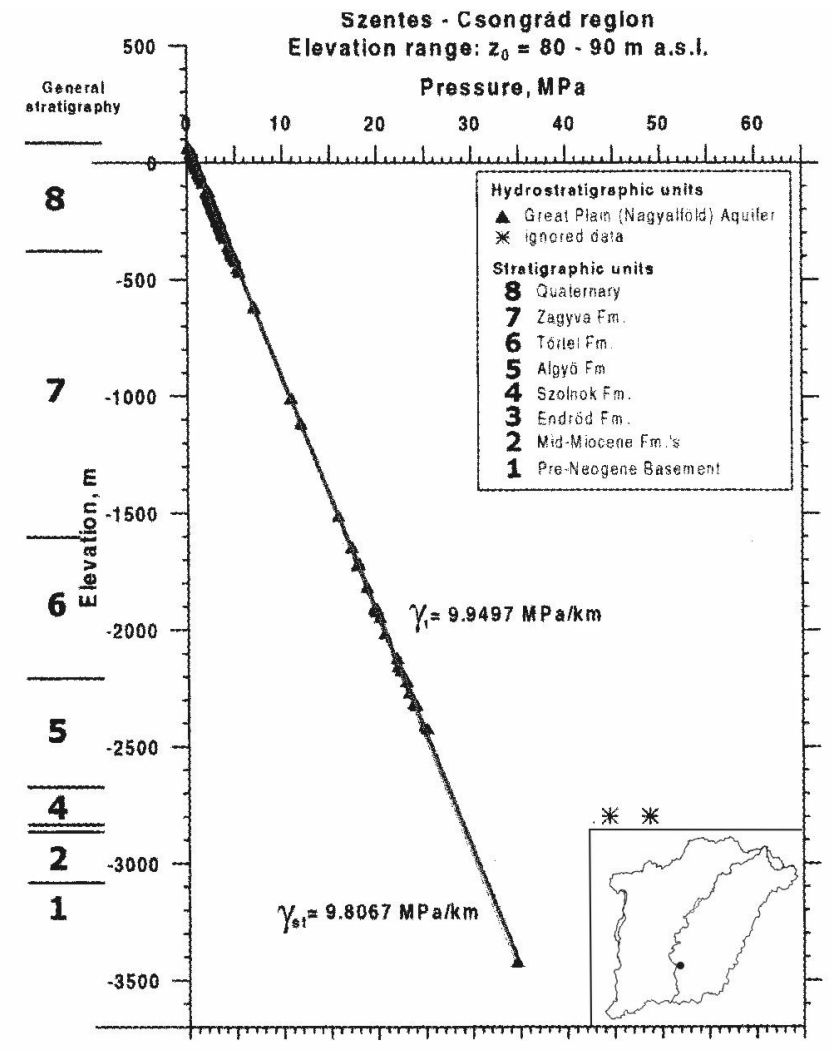

groundwater regime (Mádl-Szőnyi and Tóth 2009). Czauner (2008) proved that conductive faults in the central part of the Great Hungarian Plain can promote hydrocarbon and water migration and cause hydraulic head anomalies in the gravity flow regime. Though recent tectonic activity in the Pannonian Basin is moderate, tectonic evolution of the basin is still going on (Bada et al. 2007). Faults cut through the basement and/or the young sediments; therefore they can connect the locally different parts of the overpressured regime and the gravitational flow regime. As a consequence the delineation of the two flow regimes and the determination of the water origin (i.e. meteoric and rechargeable or closed and unrechargeable) cannot be schematized. A better understanding of the connectivity of the two flow regimes requires further research.

The upper part of the Neogene reservoir (mainly the Alföld Aquifer) is used as drinking water supply in the Great Hungarian Plain. Since the entire Neogene reservoir constitutes a hydraulically continuous system, long-term and intensive thermal water production from the deeper parts of the flow regime must be planned and regulated in order not to endanger the drinking water supply. Sustainable production planning requires as precise knowledge of the processes 


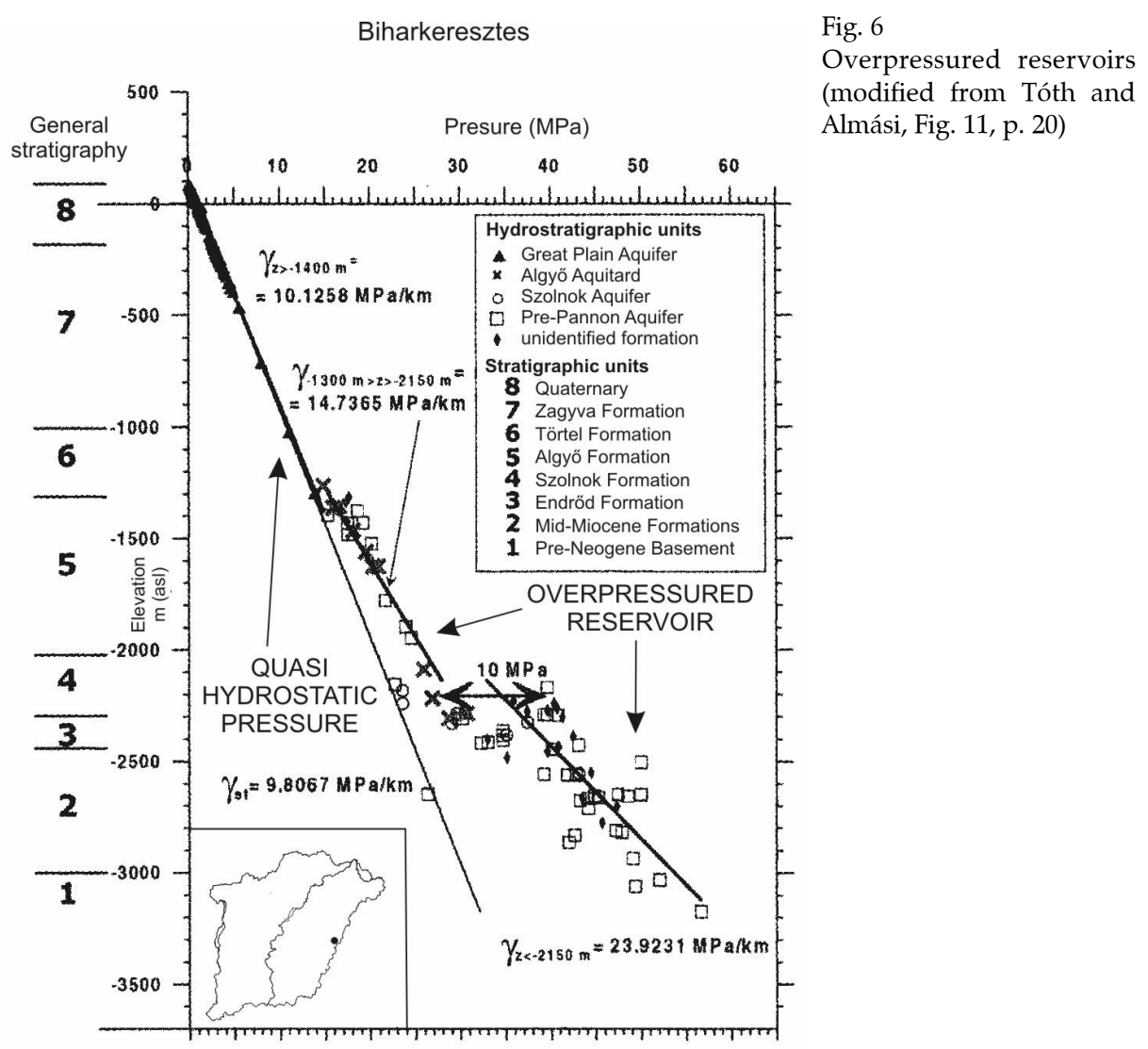

in the reservoir as possible, based on further research, continuous monitoring of production data together with pressure and temperature data, chemical analyses, data processing and modeling.

Nowadays, apart from some exceptions such as Hódmezôvásárhely and Kistelek, the thermal waters in the Great Hungarian Plain are used for heat production, mostly without reinjection. This limits the amount of heat and water that can be utilized from a reservoir and this utilization is not sustainable (Rybach and Mongillo 2006). The exploitation of water leads to decline in reservoir pressure (Liebe 2001).

If the heat at the surface is taken by heat exchangers, and the cold water is reinjected (i.e. geothermal doublet), then the pressure can be sustained. However, at the same time the temperature in the reservoir is reduced (Fig. 7). Cooling of the reservoir shows that the heat stored in the rock framework of the reservoir is also withdrawn. When heat is depleted from the reservoir then production must be suspended. Numerical models show that after production has been stopped, the recovery time of the temperature depends on the thickness of the cooled 

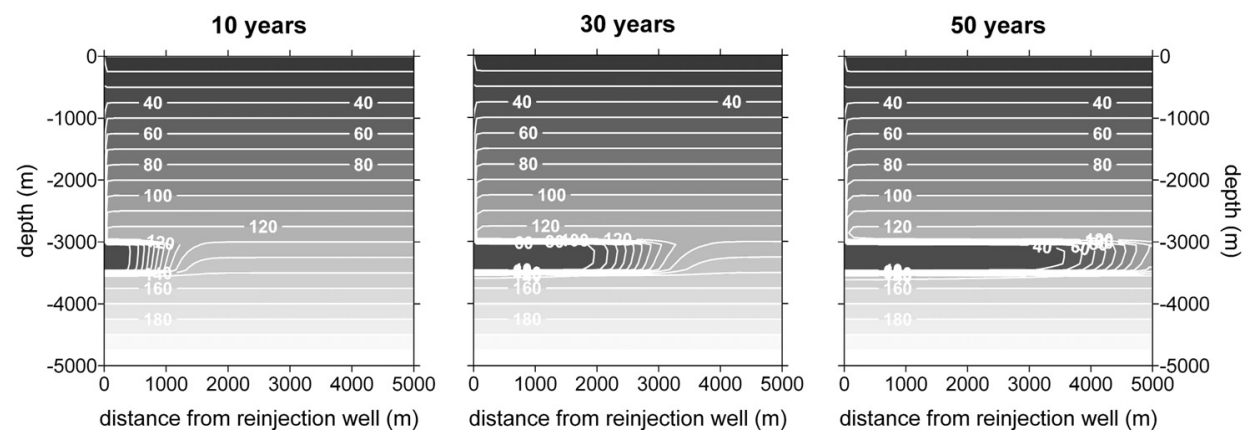

Fig. 7

Evolution of the temperature in a schematic two-dimensional heat transport model of a reinjectionproduction well doublet. Temperature contour interval is $10^{\circ} \mathrm{C}$. Reinjection and production occur on the left and right side of the model, respectively. Temperature of the reinjected water is $30^{\circ} \mathrm{C}$. The Darcy velocity of the water flow in the reservoir is prescribed $\left(50\right.$ myear $\left.^{-1}\right)$

region and the length of the production period. In the case of a few hundred meters-thick cold region and a few decades of production (as in Fig. 7) the recovery time is a few hundred years. A thinner reservoir exploited with smaller production periods recovers in a few decades (Rybach et al. 1999, 2000).

In a real case study the effect of production and reinjection on the potential and thermal conditions of a reservoir can be investigated by coupled mass and heat transfer modeling, and the model must be calibrated by the production and monitoring data.

\section{Summary}

Hungary, as a consequence of its tectonic settings, has favorable possibilities for the direct use of geothermal energy. Due to its moderately elevated temperature the entire Neogene reservoir beneath the Great Hungarian Plain can be considered as a low enthalpy reservoir. Groundwater with temperature less than $110{ }^{\circ} \mathrm{C}$ is used mainly for balneology, agriculture, communal heating and hot water supply.

The most prospective area for the utilization of geothermal heat, using the concept of production and re-injection well doublets, is the southern part of the Great Hungarian Plain, where the thickness of the Neogene reservoir is the largest, and thus the amount of stored heat is the greatest.

The geothermal heating system in Hódmezóvásárhely, consisting of production wells and reinjection wells, supplies $\sim 0.2-0.3$ PJyear $^{-1}$ of heat used for district heating, communal hot water supply and balneology. Re-injection into the Neogene sandstone has been operating properly for a decade in Hódmezóvásárhely (Kurunczi 2005). The amount of geothermal energy utilized in Hungary is 3.6 PJyear $^{-1}$ (Hungarian Energy Office). Installation of 50-100 
geothermal heating systems similar to that of Hódmezóvásárhely could increase the utilization of geothermal energy to 5-10 times that of the present value (Mádlné Szőnyi et al. 2008). The only way to achieve this goal is to work out the technology of re-injection to the Neogene sediments in parallel to investigating the hydrological, physical and chemical conditions of re-injection.

On the other hand, the intensive use of the Neogene reservoir requires a detailed knowledge of it. One of the most crucial scientific tasks in the geothermal use of the Neogene reservoir is to map the transition between the gravity-driven and the overpressured flow regime. The research topics related to resolving this task are as follows (after Tóth 2006):

i) Chemical analyses of the meteoric water (gravity-driven) and pore water (overpressure-driven) regimes using stable isotopes $\left({ }^{2} \mathrm{H},{ }^{3} \mathrm{H},{ }^{18} \mathrm{O},{ }^{13} \mathrm{C},{ }^{87} \mathrm{Sr} /{ }^{86} \mathrm{Sr}\right.$ ) and major ions to obtain their chemical characteristics, especially near basement faults;

ii) Interpretation of hydraulic head anomalies by the identification of conducting faults applying seismic data;

iii) Mapping of meteoric and pore water distribution near conducting faults using chemical, isotope and temperature data;

iv) Numerical modeling of the production characteristics of wells producing from the gravity-driven and overpressure-driven flow regimes.

Application of the results to: i) Identification of the origin of water sampled from a well; ii) Elaboration of the production protocol of wells producing from the different reservoirs based on digital models.

Combining structural geology with seismic interpretation, hydrogeochemistry, hydraulic evaluations and numerical modeling is an effective tool in the study of the groundwater flow regimes beneath the Great Hungarian Plain.

The results of the above-mentioned studies of the gravity-driven and overpressure-driven flow regimes must be incorporated into a basin-scale numerical model of the Neogene reservoir (Mádlné Szőnyi et al. 2008). Such a numerical model would be an indispensable tool in assessing and managing groundwater and geothermal energy resources. These types of models can be used to predict the response of the reservoir to the water production and injection.

\section{Acknowledgements}

This review is based on the conclusions of the study of Mádlné Szónyi et al. (2008) supported by the Hungarian Academy of Sciences. The authors gratefully acknowledge Prof. J. Tóth for his thoughts on the geothermic regime of the Great Hungarian Plain presented in 2006 at the Kistelek Conference in Hungary. We thank Prof. F. Horváth and Prof. Gy. Pogácsás for their comments, which improved the quality of the paper. 


\section{References}

Árpási, M. 2005: Geothermal Update of Hungary 2000-2004. - Proc. World Geothermal Congress 2005, 12, pp. 1-16.

Bada, G., F. Horváth, P. Dövényi, P. Szafián, G. Windhoffer, S. Cloetingh 2007: Present-day stress field and tectonic inversion in the Pannonian basin. - Global and Planetary Change, 58/1-4, pp. $165-180$.

Bertani, R. 2007: World Geothermal Power Generation in 2007. - Proceedings of the European Geothermal Congress 2007, Unterhaching, Germany, 30 May - 1 June 2007.

Bérczi, I., G. Hámor, Á. Jámbor, K. Szentgyörgyi 1988: Neogene sedimentation in Hungary. - In: Royden, L.H., F. Horváth (Eds): The Pannonian Basin, a Study in Basin Evolution, pp. 57-67. American Association of Petroleum Geologists Memoir 45, Tulsa, OK.

Bodri, L. 1981: Geothermal model of the Earth's crust in the Pannonian Basin. - Tectonophysics, 72, pp. 61-73.

Csontos, L., A. Nagymarosy, F. Horváth, M. Kovác 1992: Tertiary evolution of the Intra-Carpathian area: a model. - Tectonophysics, 208, pp. 221-241.

Czauner, B. 2008: Vetôk hidraulikai viselkedésének komplex vizsgálata Berekfürdő térségében (The Evaluation of Hydraulic Behavior of Faults in the Area of Berekfürdô). - MSc Thesis, Eötvös Loránd University, Budapest, Hungary. (In Hungarian.)

Dövényi, P., F. Horváth, D. Drahos 2002: Hungary. - In: Hurter, S, R. Haenel (Eds): Atlas of Geothermal Resources in Europe. Publication No. 17811 of the European Commission, Office for Official Publications of the European Communities. L-2985, Luxembourg. pp. 36-38.

Erdélyi, M. 1976: Outlines of the hydrodynamics and hydrochemistry of the Pannonian basin. Acta Geol. Acad. Sci. Hung., 20, pp. 287-309.

Fridleifsson, I.B., R. Bertani, E. Huenges, J. Lund, A. Rangnarsson, L. Rybach 2008: The possible role and contribution of geothermal energy to the mitigation of climate change. - Proceedings IPCC Climatic Scoping Meeting Lübeck.

Juhász, Gy. 1991: Lithostratigraphic and sedimentological framework of the Pannonian (s.l.) sedimentary sequence in the Hungarian Plain (Alföld), eastern Hungary. - Acta Geologica Hungarica, 34, pp. 53-72.

Kilényi, É., A. Kröll, D. Obernauer, J. Šefara, P. Steinhauser, Z. Szabó, G. Wessely 1991: Pre-Tertiary basement contour map of the Carpathian Basin beneath Austria, Czechoslovakia and Hungary. - Geophys. Trans., 36, pp. 15-36.

Kurunczi, M. 2005: Geotermia a gyakorlatban. A hódmezővásárhelyi geotermikus közmúrendszer bemutatása (Geothermics in Practice. Introducing the Geothermal Municipal Water Works in Hódmezóvásárhely). - Manuscript, 5 (In Hungarian.)

Lenkey, L. 1999: Geothermics of the Pannonian basin and its bearing on the tectonics of basin evolution. - PhD Thesis, Vrije Universiteit, Amsterdam $215 \mathrm{p}$

Liebe, P. 2001: Thermal water resources in Hungary, their utilisation and Protection. - Completed by the Hydrological Institute of VITUKI Plc. commissioned by the Ministry of Environment Hungary Budapest 2001 http://www.kvvm.hu/szakmai/karmentes/kiadvanyok/fav/tvka/tvka_index.htm.

Lund, J.W., D.H. Freeston, T.L. Boyd 2005: World-wide direct uses of geothermal energy 2005. Proceedings World Geothermal Congress, 2005 Antalya, Turkey, 24-29 April, 2005.

Mádlné Szőnyi, J. 2006: A geotermikus energia, Készletek, kutatás, hasznosítás (Geothermal Energy. Resources, Research, Utilization). - Grafikon Kiadó, Nagykovácsi. (In Hungarian.)

Mádlné Szőnyi, J., L. Rybach, L. Lenkey, T. Hámor, F. Zsemle 2008: A geotermikus energiahasznosítás nemzetközi és hazai helyzete, jövőbeni lehetőségei Magyarországon. Ajánlások a hasznosítást előmozdító kormányzati lépésekre és háttértanulmány (International and Hungarian Status Quo of Geothermal Energy Utilization. Recommendations for the Government to Facilitate Utilization). - Manuscript for the Hungarian Academy of Sciences, pp. 1-105. (In Hungarian.) 
Mádl-Szőnyi, J., J. Tóth 2009:: A hydrogeological type section for the Duna-Tisza Interfluve, Hungary. - Hydrogeology Journal. DOI: 10.1007/s10040-008-0421-z.

Mc Farland, T. 2002: Geothermal Energy and why I like it. - Manuscript, http://www.indiana.edu/ sierra/papers/2002/mcfarland.pdf.

Pollack, H.N., S.J. Hurter, J.R. Johnson 1993: Heat loss from the Earth's interior: analysis of the global data set. - Reviews of Geophysics, 31, pp. 267-280.

Royden, LH., F. Horváth, A. Nagymarosy, L. Stegena 1983: Evolution of the Pannonian basin system: 2. Subsidence and thermal history. - Tectonics, 2, pp. 91-137.

Rybach, L., Th. Mégel, W.J. Eugster 1999: How renewable are geothermal resources? - Geothermal Resources Council Transactions (17-20 October), 23, pp. 563-566.

Rybach, L., Th. Mégel, W.J. Eugster 2000: At what timescale are geothermal resources renewable? In: Proceedings World Geothermal Congress 2000, Kyushu, Tohuku, Japan. pp. 867-873.

Rybach, L., M. Mongillo 2006: Geothermal Sustainability. A review with Identified Research Needs. - In: Geothermal Research Council 2006 Annual Meeting, San Diego, California 10-13 September 2006.

Schulhof, Ö. (Ed.) 1957: Magyarország ásvány- és gyógyvizei (Mineral waters and spas in Hungary). - Akadémiai Kiadó, Budapest, 963 p. (In Hungarian.)

Tóth, J. 2006: Az alföldi hévizek kettôs eredete és annak gyakorlati következményei: egy megfigyelésekre alapozott hipotézis (The Double Sources of Thermal Waters in Hungarian Great Plain and its Practical Consequences: a Hypothesis Based on Observations). - Geotermia és Környezetipar a XXI. Században, Szakkiállítás és Konferencia (Geothermics and Environmental Industry in the 21st Century, Conference), Kistelek, 30-31 January 2006. (In Hungarian.)

Tóth, J., I. Almási 2001: Interpretation of observed fluid potential patterns in a deep sedimentary basin under tectonic compression: Hungarian Great Plain, Pannonian Basin. - Geofluids, 1/1, pp. 11-36.

Vakarcs, G, P.R. Vail, G. Tari, Gy. Pogácsás, R.E.Mattick, A. Szabó 1994: Third-order Middle Miocene-Early Pliocene depositional sequences in the prograding delta complex of the Pannonian basin. - Tectonophysics, 240, pp. 81-106.

WEA 2000: World Energy Assessment: Energy and the Challenge of Sustainability. - United Nations Development Programme/UN-DESA/ World Energy Council, New York, 500 p.

Zsigmondy, V. 1871: Tapasztalataim az artézi szökőkutak fúrása körül (My experiences in artesian well drillings). - Értekezések a Természettudományok köréból (Natural Science Essays). Magyar Tudományos Akadémia, Pest, 46. (In Hungarian.) 